\title{
The structural aspect in the ecology of sea-grass communities
}

\author{
Cornelis den Hartog
}

Rijksherbarium, Leyden, Netherlands

\begin{abstract}
KURZFASSUNG: Der strukturelle Aspekt in der Ökologie von Seegras-Gemeinschaften. Seegräser sind aquatische Angiospermen, welche vollkommen an das Leben im Meer angepaßt sind. Sie gehören zu zwei Familien, den Potamogetonaceen mit 9 und den Hydrocharitaceen mit 3 marinen Gattungen. Für das Leben im Meer sind sie gut ausgerüstet mit Eigenschaften, die unbedingt für eine erfolgreiche Existenz erforderlich sind: hohe Salztoleranz, Fähigkeit, ganz untergetaucht zu gedeihen, Vorhandensein gut entwickelter Rhizome, hydrophile Bestäubung und ein ausreichendes Konkurrenzvermögen. Eine erfolgreiche Ansiedlung im Meer ist bereits ausgeschlossen, wenn die zuletzt erwähnte Eigenschaft nicht vorhanden ist. Es gibt nämlich eine Reihe von Gattungen, die in ihrer Beziehung zur Umwelt, insbesondere zum Salzgehalt, eine viel größere Toleranz besitzen als die Seegräser, aber ungenügend konkurrenzfähig sind gegenüber stenobionten Wasserpflanzen. Diese Gattungen sind beschränkt auf poikilohaline Gewässer und unstabile Süßwasserbiotope. Die Gesellschaften dieser Pflanzen werden zur Klasse der Ruppietea gestellt. Die echten Seegrasgesellschaften werden zusammengefaßst in der Klasse Zosteretea. Diese Gesellschaften sind noch ungenügend studiert worden; daher wird ihre Struktur von vielen Pflanzensoziologen nicht korrekt beurteilt. Der Verfasser bereitet eine Monographie über die Seegräser vor; er hatte Gelegenheit, alle bis jetzt bekannten Arten gründlich zu untersuchen und die Wichtigkeit ihrer morphologischen Merkmale für die OOkologie zu prïfen. Es stellte sich heraus, daß unter den Seegräsern 6 Wuchsformen unterschieden werden können, welche charakterisiert sind durch das Verästelungssystem, die Blattform und die Natur der Blattscheiden. Jede Wuchsform hat ihren eigenen Platz in der Zonierung und in der Sukzessionsreihe, und jede bedingt im großen und ganzen die Struktur der von ihr konstituierten Pflanzengesellschaft.
\end{abstract}

\section{INTRODUCTION}

Sea-grasses are aquatic angiosperms which are completely adapted to life in the sea. They occur in shallow coastal waters and are able to penetrate to some extent into estuaries and other brackish waters; they are, however, completely absent in fresh water. The exceptional ecological position of the sea-grasses is also demonstrated by the taxonomical composition of the group. Altogether 47 species are considered to be sea-grasses. These are grouped into 12 genera, 9 of which belong to the Potamogetonaceae sensu lato and the other 3 to the Hydrocharitaceae, both families being classified into the monocotyledonous order of the Helobiae. The taxonomical composition of the group is shown in Table 1. 
Table 1

Taxonomical composition of the group of the sea-grasses

\begin{tabular}{|clc|}
\hline $\begin{array}{c}\text { Families } \\
\text { and subfamilies }\end{array}$ & \multicolumn{1}{c}{ Genera } & Number of species \\
\hline Potamogetonaceae: & Zostera & 11 \\
Zosteroideae & Pbyllospadix & 5 \\
& Heterozostera & 1 \\
Posidonioideae & Posidonia & 3 \\
Cymodoceoideae & Halodule & 6 \\
& Cymodocea & 4 \\
& Syringodium & 2 \\
& Amphibolis & 2 \\
Thalassodendron & 1 \\
Hydrocharitaceae: & Enbalus & 2 \\
Hydrocharitoideae & Thalassia & 8 \\
Thalassioideae & Halophila & \\
Halophiloideae & & \\
\hline
\end{tabular}

\section{PROPERTIES REQUIRED FOR LIFE IN THE MARINE ENVIRONMENT}

According to Arber (1920) there are four properties, which are indispensable for a marine water plant. In the first place, it must be adapted to life in a saline medium. Secondly, it must be able to grow when completely submerged. Thirdly, it must have at its disposal an anchoring system which is sufficiently developed to withstand wave action and tidal currents. Finally, it must have the capacity for hydrophilous pollination because no aerial method seems to be effective. In other words, the plants must be able to achieve their vegetative as well as their generative cycle in a saline medium, while completely submerged, and must be securely anchored in the substrate or be fixed to the substrate.

All sea-grasses possess the first two properties. Furthermore, sea-grasses possess more or less strong rhizomes, which are branched sympodially or monopodially, depending on the genus, and show a tendency to grow in large groups; this fulfills the third requirement. Finally, all sea-grasses are well-equipped for hydrophilous pollination, for which a remarkable scale of variation exists. Entirely submerged pollination takes place in most genera. Adaptations to this type of pollination are the confervoid pollen grains of the Potamogetonaceous sea-grasses and the moniliform chains of globular pollen grains of the genera Thalassia and Halopbila. Other adaptations are the elongate hypanthia of Thalassia and Halophila, the long styles in Halophila and Halodule, and the very long stigmata in Cymodocea, Amphibolis and Thalassia. Semi-aquatic surface pollination, whereby the pollen drifts on the water surface and the styles are at least partially in contact with the water surface, has been described for Phyllospadix (Dudley 1893) and Zostera, but in these genera completely submerged pollination occurs just as often. Aerial surface pollination, whereby the pollen as well as the styles remain dry, is shown by Enbalus acoroides (L. f.) RICH. ex STEUD. The florrer biology of this species is completely adapted to the tidal cycle (Svedelius 1904, Troll 1931, Den Hartog 1957). 
Although all sea-grasses satisfy the 4 criteria of ARBER, there are a few other taxa which also fulfill these conditions, viz. Zannichellia, Lepilaena, Althenia, Ruppia and Potamogeton subgen. Coleogeton (with $P$. pectinatus L.), all of which are representatives of the family Potamogetonaceae. The range of salinity which they can tolerate is greater than that of the sea-grasses, as they are to be found in fresh water, in brackish water and in hypersaline waters where the salt-content of the sea may be considerably exceeded ${ }^{1}$. Further, they are able to stand much greater and sudden fluctuations in salinity. With relation to the chemical composition of the salt water, they are not quite as restricted as the sea-grasses. Ruppia, for example, occurs not only in waters where $\mathrm{NaCl}$ is the dominating salt, but also in waters where $\mathrm{Na}_{2} \mathrm{SO}_{4}$ and $\mathrm{MgSO}_{4}$ are the dominating salts. Zannichellia and Potamogeton pectinatus inhabit waters where $\mathrm{Na}_{2} \mathrm{CO}_{3}$ is the dominant salt. Nevertheless, these euryhaline taxa seldom penetrate into the purely marine environment. They sometimes occur together with the most euryhaline sea-grasses in brackish waters such as estuaries and lagoons. Generally, they appear to be restricted to poikilohaline waters, i. e. waters characterized by an instable salinity. The inability of these taxa to populate the marine environment must be ascribed to a low competition capacity, as it does not lie with their tolerance to salinity. It is probably a basic rule of ecology that a wide tolerance with relation to environmental fluctuations is coupled with a reduced capacity to compete with more stenobiontic taxa in more or less stable habitats.

In this respect it is interesting that the late Dr. E. Y. DAwson collected Ruppia maritima L. in Peru under true marine conditions in an environment where sea-grasses would normally be expected. Thus in salt waters two groups of water plants can be distinguished: (1) the true sea-grasses (Table 1), which are more or less stenohaline and confined to the homoiohaline, marine environment, and (2) the group of extremely euryhaline genera which are neither marine nor maritime but confined rather to poikilohaline waters.

There are some representatives of the second group, which can thrive in fresh water occurring especially in places subjected to instable environmental factors, e. g. in waters where the level strongly fluctuates and which sometimes dry up completely, or in places where two types of water of different chemical composition mix.

In the phytocenological system these two groups are classified separately. The communities of the true sea-grasses are placed in the class of the Zosteretea, while the communities of the euryhaline taxa are for the greater part placed in the class of the Ruppietea (Den Hartog \& Segal 1964).

\section{GROWTH-FORMS OF SEA-GRASSES}

Sea-grasses show a high degree of uniformity in their vegetative appearance. All genera have well-developed subterranean rhizomes and linear or strap-shaped leaves. It is only in the genus Halophila that other leaf-shapes, e. g. elliptic, ovate and lanceolate leaves, also occur. Therefore, sea-grasses generally have been regarded as an $1964 \mathrm{~b})$.

1 Ruppia spiralis L. ex Dum. has been found even at a salinity of $64 \% \mathrm{Cl}^{\prime}$ (Den Hartog 
homogeneous group and in growth-form systems they were referred to as "enhalids". A closer study showed, however, that they exhibit a considerable degree of diversity in the mode of growth, in the branching system and in the anatomical structure. According to the growth-form system, recently developed by Den Hartog \& Segal (1964), the sea-grasses are comprised of more than one category, the vallisneriids, the elodeids, and a third category composed of the majority of the Halophila species. Further subdivision of the sea-grasses is possible, however:

(A) Vegetative system monopodially branched; herbaceous.

(1) Parvozosterids, with fine linear leaves: Halodule, Zostera subgen. Zosterella.

(2) Magnozosterids, with wide linear leaves, the laminae of which are shed before the sheaths; these sheaths either decay completely or remain membranous, but do not persist as fibres: Zostera subgen. Zostera, Cymodocea, Thalassia.

(3) S y ri n g o d i id s, with long subulate leaves: Syringodium.

(4) En h a lids, sensu stricto, with leathery linear or coarse strap-shaped leaves, the laminae of which are shed before the leaf-sheaths; the remains of the sheaths form thick paint-brushlike fibre bundles at the base of the plant: Enhalus, Posidonia, Phyllospadix.

(5) $\mathrm{Ha}$ o philids, delicate plants with elliptic, ovate, lanceolate or linear leaves: Halophila ${ }^{1}$.

(B) Vegetative system sympodially branched, lignified.

(6) Amphibolids, with erect vegetative stems: Amphibolis, Thalassodendron, Heterozostera.

Between some of these categories transitional cases occur. Wide-leaved forms of Halodule uninervis (ForsK.) Aschers. and Zostera capricorni Aschers. fit in quite well in the magnozosterids, while narrow forms of Zostera marina L. or Cymodocea nodosa (UCRIA) Aschers. are perhaps better classified as parvozosterids. The separation of magnozosterids and enhalids is stricter. Although coarse forms of Thalassia testudinum BANKS ex König sometimes closely approach the enhalid growth-form, their sheaths never persist as fibrous bundles.

The various growth-forms seem to be linked with differences in ecological behaviour. This is particularly obvious in the tropical and subtropical seas, where the number of species is higher than in the temperate seas, and where a distinct zonation can be observed. Species of Halodule often form extensive vegetations in the intertidal belt of the tropical seas. At about low-water-mark, or, more exactly, between the levels of mean low-water neap (MLWN) and mean low-water springs (MLWS), the parvozosterid Halodule vegetation becomes replaced by a vegetation of coarser seagrasses like Thalassia and Cymodocea which belong to the magnozosterids. In the upper sublittoral the magnozosterid vegetation becomes replaced in its turn by the very coarse amphibolids and enhalids. At the greatest depths in which angiosperms are able to live, they are usually represented by the tiny halophilids.

The general sequence of the zonation of the sea-grass communities is not often

1 Halophila stipulacea (Forsk.) Aschers. can also be regarded as a parvozosterid. The branching system of $H$. spinulosa (R. BR.) Aschers., the habit of which shows a striking similarity to that of Groenlandia densa (L.) FourR., needs reinvestigation. 
realized. Local hydrographic or edaphic circumstances, absence of representatives of certain growth-forms in extensive areas, and disturbances of the vegetation by natural or human factors often cause the zonation to become simplified and incomplete. These deviations from the ideal pattern of zonation make it possible to gain an insight into the ecological capacities of the various genera.

Closed vegetations of Halodule species occur not only in the intertidal belt; they also occur at low-water-mark and in the sublittoral. When a bed of Thalassia testudinum has become damaged by a storm, shipping or other causes, the empty space soon becomes populated by Halodule beaudettei (Den Hartog) Den Hartog. After a time Thalassia begins to penetrate into the Halodule vegetation, pushing it back and finally superseding it (Phillips 1960, Strawn 1961, Moore 1963). H. beaudettei is also dominant in the sublittoral when coarser sea-grasses are absent, e. g. along the Pacific coast of Central America (Den Hartog 1961). It is noteworthy that Halodule species penetrate further into the estuaries than do species of Thalassia, Cymodocea and Syringodium. Generally, the Halodule species behave as rather eurybiontic pioneer species, which are only permanent in biotopes unfavourable to the other more stenobiontic species or in biotopes where the latter are absent.

Representatives of the genus Halopbila also occur almost everywhere from the intertidal belt down to a considerable depth. Unlike Halodule, the ecological range of the separate species of Halophila is not equal to the ecological range of the genus. H. ovalis (R. BR.) Hook. f. and H. stipulacea often grow in the company of Halodule species in the intertidal belt, locally forming pure stands; they occur also lower down, intermingled with Cymodocea rotundata EHRENB. \& HEMPR. ex AsCHERs. \& SCHWEINF., C. serrulata (R. BR.) Aschers. \& MAGNUS, Syringodium isoetifolium (Aschers.) DANDy, Thalassia bemprichii (EHrenb.) Aschers. and Enhalus acoroides. The annuals Halophila minor (Zoll.) Den Hartog and H. beccarii Aschers., which can occur on mud as well as on sand bottoms, are mainly intertidal; the first-mentioned species, however, is confined to euhaline shores, while the latter seems to be restricted to brackish estuaries. $H$. decipiens Ostenfeld, H. spinulosa (R. Br.) Aschers., H. baillonis Aschers. ex Hook. f. and $H$. engelmanni Aschers. occur mainly in deep water; they are sometimes found near low-water-mark in the undergrowth of dense vegetations of coarser sea-grasses, e. g. in Thalassia beds, which provide the necessary shade and shelter.

The other growth-forms are much more restricted with respect to their occurrence. The Syringodium species with their stiff, subulate leaf-blades, the erect amphibolids and the coarse Posidonia species do not stand desiccation, not even for very short periods, and as a matter of course they populate the upper sublittoral. Their lower limit is determined by the light conditions and therefore is largely dependent on the transparency of the water. Extensive sea-grass meadows generally do not occur below a depth of 10 to $12 \mathrm{~m}$, although several species may occur scattered at a much greater depth. Posidonia oceanica (L.) Delite is the only species for which beds have been reported from depths to ca. $30 \mathrm{~m}$ (Feldmann 1937). Enhalus acoroides is also restricted to the upper fringe of the sublittoral owing to its flower biology. The vegetations of the amphibolids and enhalids are usually very dense, so that there is hardly any place left for other bottom-rooting species. When, however, enhalids and amphibolids 


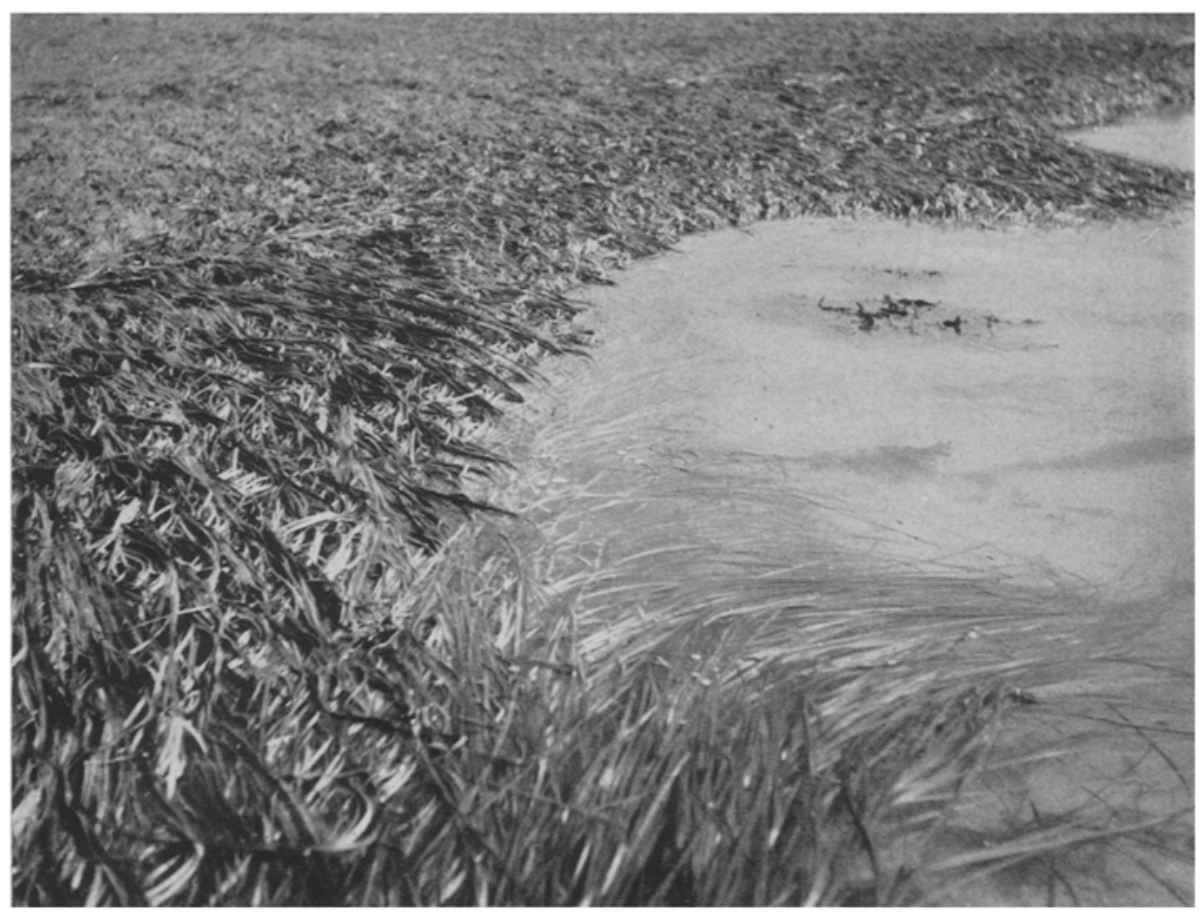

Fig. 1: Bed of Zostera marina I. at Herm (Channel Islands) on sandy bottom, during a very low spring tide. The Zostera bed is confined to the area around low-water-mark and does not extend downwards (September 1960)

are absent from an area, their place is taken by magnozosterids, which elsewhere mainly inhabit the belt around low-water-mark. This is obvious in the Caribbean, where the magnozosterid Thalassia testudinum is the dominant sea-grass in the sublittoral, where it forms extensive, dense beds (Phillips 1960). In the Indo-Pacific waters beds of Thalassia hemprichii, Cymodocea rotundata, C. serrulata and wideleaved Halodule uninervis are usually limited to the area around low-water-mark, being replaced in the sublittoral by dense vegetations of Thalassodendron ciliatum (Forsk.) Den Hartog or Enbalus acoroides (Macnae \& Kalk 1958, 1962, PhamHoANG Ho 1961). Where the two last-mentioned species are absent, the magnozosterids may extend to a considerable depth (Tanaka, Nozawa \& Nozawa 1962), and the vegetation is supplemented with Syringodium isoetifolium. A similar situation has been recorded from the Mediterranean, where Cymodocea nodosa often precedes Posidonia oceanica in the succession and reappears again when the Posidonia beds become degraded (Molinier \& Picard 1951, Aleem 1955).

Table 2 shows the zonation pattern of the genera grouped according to the growth-forms. It appears that in the eulittoral parvozosterids are dominant, often accompanied by halophilids. Around low-water-mark they become replaced as dominants by magnozosterids, which in the sublittoral have to give way to the coarse 
T'able 2

Zonation pattern of the growth-forms

\begin{tabular}{|c|c|c|c|c|c|c|}
\hline Growth-form & 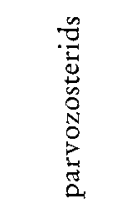 & 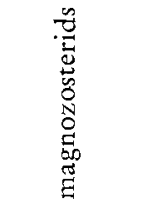 & 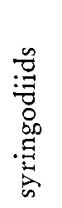 & 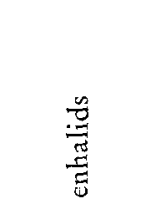 & 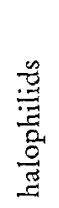 & 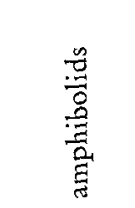 \\
\hline Genus & 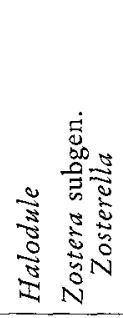 & 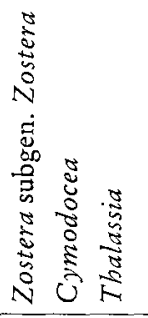 & 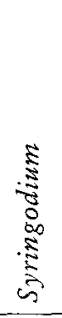 & 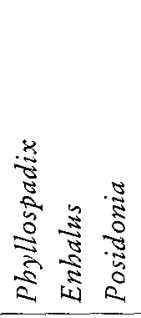 & $\frac{\sqrt{1}}{\frac{3}{0}}$ & 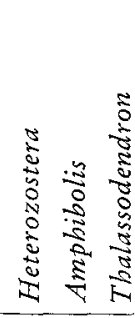 \\
\hline $\begin{array}{l}\text { Mid-eulittoral } \\
\text { Belt between }\end{array}$ & ++ & --- & - & --- & + & --- \\
\hline MLWN and MLWS & ++ & +++ & - & +-- & + & +-- \\
\hline Upper sublittoral & +- & +++ & + & +++ & + & +++ \\
\hline Lower sublittoral & +- & --- & - & --+ & + & --- \\
\hline
\end{tabular}

enhalids and amphibolids when these are present. In the lower sublittoral sciophilous halophilids, which are only scattered in the undergrowth of the upper sublittoral seagrass vegetations, become able to form independent communities without admixture of other sea-grasses.

The places of the various growth-forms in the succession series coincide with their places in the zonation. Parvozosterids and halophilids form separately or together the pioneer communities and are followed by magnozosterids and syringodiids. These in their turn are followed by enhalids or amphibolids or mixed vegetations of both growth-forms.

\section{THE STRUCTURE OF THE SEA-GRASS COMMUNITY}

Phytocenologists generally consider the sea-grass communities to be of a very simple structure. In a recent survey by LoHMEIJER c. s. (1962), in which the higher phytocenological units of Central and North-western Europe were arranged according to their sociological progression, i. e. according to increasing structural complexity, the Zosteretea were placed at the very beginning of the system, together with the Lemnetea. Other classes of water plants such as the Ruppietea and the Potametea were classified with obviously higher organized vegetation units. It must be admitted that the sea-grass communities are poor in species and generally do not exhibit the variety 


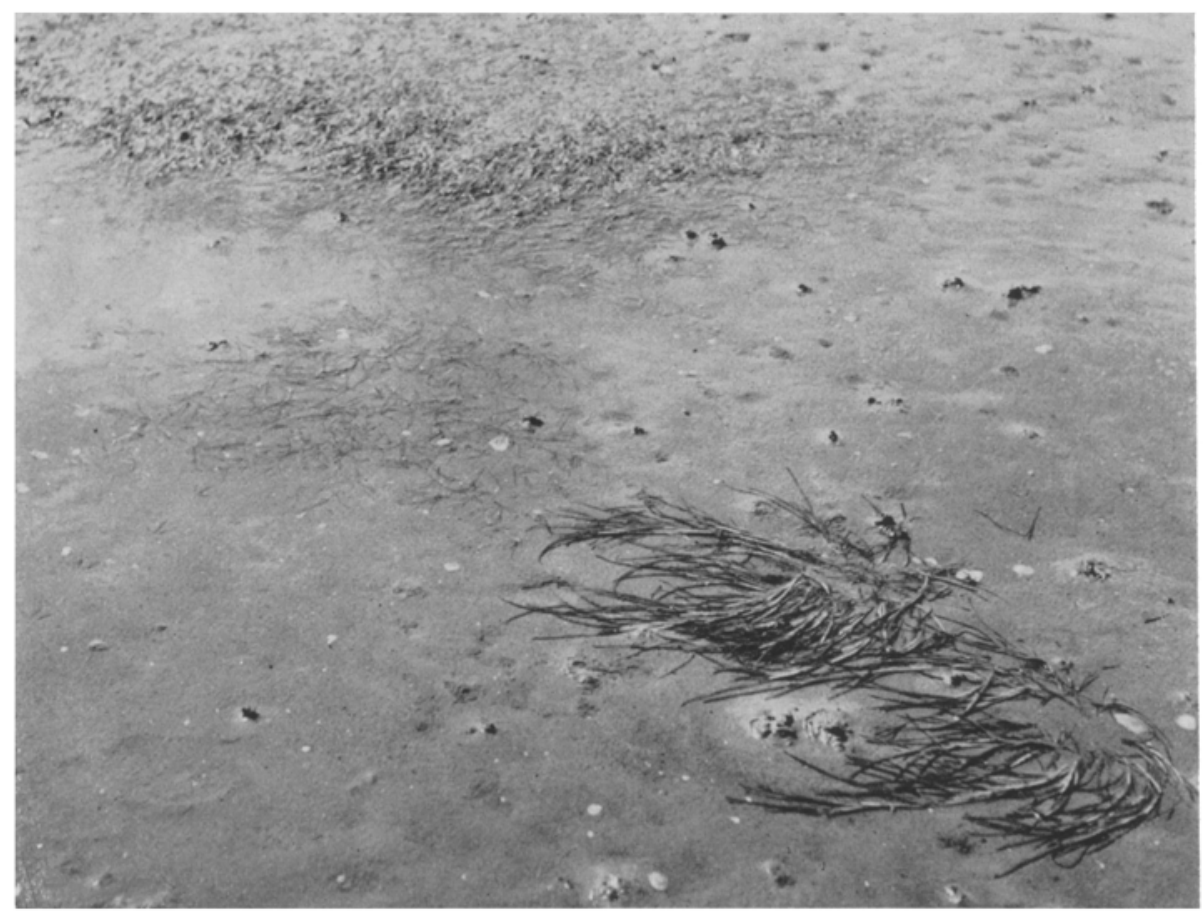

Fig. 2: Mixed vegetation of Zostera noltii HonNEM. and Z. marina L. on detritus-rich fine sand on the intertidal flat of Kattendijke (Netherlands). Z. noltii mainly inhabits the small well-drained elevations, while $Z$. marina is confined to the little depressions in the flat, where the plants remain covered by a thin layer of water, also during low tide (August 1965)

of growth-forms which is found in the limnetic water-plant communities of the Potametea. From a structural point of view there are, however, few differences between the various classes of rhizophytic water plants. As in the case of the limnetic waterplant communities, the sessile frame-work of sea-grass communities is almost completely composed of one layer of angiosperms; in tropical and subtropical waters "rhizophytic" algae, e. g. species of Penicillus and Caulerpa, may also be included in the composition of the vegetation, especially in the more open sea-grass beds. The density of the vegetation is to a high degree determined by the mode of growth of the component species. Species with long and thin internodes form relatively open communities, while the species with short, contracted internodes and the sympodially branched species with their numerous upright stems form very dense beds.

The organization within the sea-grass communities is in fact a function of the succession. The organization of an eulittoral vegetation of parvozosterids is very simple; there are hardly any epiphytes or other accompanying species, and its bottom fauna shows only quantitative differences, if any, when compared with the bottom fauna of similar eulittoral biotopes without vegetation. The same is true for the vegetations dominated by Halophila species.

The vegetations of magnozosterids show, however, a definite differentiation. In 
well-developed beds of Zostera marina and Thalassia testudinum the leaf-blades, particularly their apical parts, become densely overgrown by algae, bryozoa, hydroids, tunicates, sponges, etc. Humm (1964) recorded for Thalassia testudinum in Florida 113 algal epiphytes. The number of epiphytes of Zostera marina is certainly of the same order. Most of these algae are only facultative epiphytes, which grow on rock and algae as well. Some of them seem to have their greatest abundance in sea-grass vegetations. The number of species confined exclusively or almost exclusively to sea-grasses and completely adapted to the growth rhythm of the leaves is fairly small. Rhodophycean examples are Rbodophysema georgii BATT., Melobesia lejolisii Rosan. and Erythrotrichia bertholdii BATT., and Phaeophycean examples are Cladosipbon zosterae (J. Ag.) KYLIN, C. occidentalis KYLIN, Myriotrichia clavaeformis HaRv., M. subcorymbosa (Holden) BlomQuis', Ascocyclus magnusii SAUv., and Stictyosiphon subsimplex Holden. This list will certainly be extended when sea-grasses in other parts of the world have been subjected to intensive ecological investigations.

While most of the epiphytes occur the whole year round, other species are present only during a limited period of the year. The distribution of the epiphytes on the leaves also shows some differentiation. Rbodopbysema georgii and Acrochaetium species usually form a red fringe at the leaf-edges, but are absent on the flat sides of the leaves. Many species occur in the somewhat worn apical leaf-parts. The crustaceous epiphytes, e. g. Ascocyclus, Myrionema, Melobesia, Epilithon and Corallina, also occur on the smooth leaf-surfaces. The lime-encrusted Melobesia species form in their turn a suitable environment for the germination of epiphytic algae, which do not occur on the surface of the sea-grass leaves themselves. Strong epiphyte development leads to early mortality of leaves.

The most pronounced differentiation is shown by the very dense communities of enhalids and amphibolids. The epiphytic vegetation of the Posidonia oceanica community in the Mediterranean consists in fact of 2 different associations (Molinier 1959-60, 1960, Kerneïs 1960). On the leaves an association of photophilous algae occurs, the floristic composition of which shows an obvious affinity to the epiphytic associations on Zostera and Thalassia leaves. On the rhizomes a sciophilous association dominated by Peyssonnelia squamaria (GMEL.) DeCne and Udotea petiolata (TURra) BørG. occurs; this association has already been described by FELDMANN (1937) from shaded sublittoral rocks in sheltered places where it was completely independent of Posidonia.

\section{FUNCTIONS OF THE SEA-GRASS COMMUNITIES}

Increased complexity of the sea-grass communities increases their influence on the physical environment. The parvozosterids and halophilids exercise only a rather small influence on their surroundings; their main function is stabilizing the bottom. The more closed vegetations of magnozosterids, enhalids and amphibolids slacken the water movements, causing sedimentation of suspended matter. The plants themselves produce great quantities of litter; part of this material is deposited on the bottom of the seagrass bed; most of it, however, drifts away and becomes washed upon the beach or sinks to the bottom in deeper water. The dense vegetations of sea-grasses consolidate 
the bottom very effectively. Thomas, MOORE \& Work (1961) described the influence of the tropical hurricane Donna on beds of Thalassia testudinum in Florida and found that although a great deal of Thalassia leaves were washed ashore, the beds themselves appeared to be hardly damaged. Stabilization of the bottom during hurricanes is, according to STRAWN (1961), one of the major benefits derived from sea-grass meadows.

The sea-grass vegetations are of further importance as food resources, shelters and nurseries for many marine organisms. Although the number of marine organisms feeding on the sea-grass itself is not very high, the food facilities of the sea-grass beds are very extensive due to the numerous epiphytes. The sea-grass vegetations which become uncovered during low-tide are of paramount importance as a food resource for many water fowl. This became obvious when in 1931 Zostera marina was struck by the wasting disease which strongly reduced its numbers in a large part of its Atlantic area.

\section{SUMMARY}

1. Sea-grasses are aquatic angiosperms which are completely adapted to life in the marine environment. They belong to 2 families, the Potamogetonaceae with 9 marine genera and the Hydrocharitaceae with 3 marine genera.

2. All sea-grasses satisfy the following indispensable conditions for a successful existence in the sea: (a) high salt tolerance, (b) ability to grow when fully submerged, (c) well-developed rhizomes, (d) hydrophilous pollination, and (e) sufficient competitive power in the marine environment.

3. Plant taxa which fulfill the first 4 conditions excellently, but have a reduced competition capacity, are unable to establish themselves successfully in the marine environment and are restricted to poikilohaline environments, such as brackish waters and continental salt waters. Moreover, some of these taxa occur in instable fresh-water environments.

4. Within the group of the sea-grasses 6 different growth-forms can be distinguished: parvozosterids, magnozosterids, syringodiids, enhalids, halophilids and amphibolids.

5. The growth-forms are linked with the environmental conditions: they show a distinct horizontal zonation and in the succession series they follow each other in a fixed sequence.

6. The structure of the communities is also dependent on the dominating growthforms. The communities of parvozosterids and halophilids are very simple in structure. The magnozosterid vegetations show some differentiation. In the enhalid and amphibolid communities a marked stratification occurs, as an upper layer, characterized by photophilous epiphytes on the leaves, and a lower layer with sciophilous epiphytes on the rhizomes can be distinguished.

7. Sea-grass communities alter the physical environment by stabilizing the bottom, slackening the water movements and increasing the sedimentation.

8. Sea-grass vegetations form a food resource for many marine organisms and water fowl, and are also of some importance as shelter and nurseries for a number of animal species. 


\section{LITERATURE CITED}

Aleem, A. A., 1955. Structure and evolution of the sea-grass communities Posidonia and Cymodocea in the south-eastern Mediterranean. In: Essays in the natural sciences in honor of Captain Allan Hancock... Univ. of S. Calif. pr., Los Angeles, 279-298.

Arber, A., 1920. Water plants; a study of aquatic angiosperms. Univ. pr., Cambridge, $436 \mathrm{pp}$.

Ascherson, P., 1906. Die geographische Verbreitung der Seegräser. In: Anleitung zu wissenschaftlichem Beobachten auf Reisen. Hrsg. von G. von Neumayer. 3. Aufl. Jaenicke, Hannover, Bd 2, 389-413.

DudbeY, W. R., 1893. The genus Phyllospadix. In: The Wilder quarter century book: a collection of original papers, dedicated to B. G. Wilder .... Comstock, Ithaca, N. Y., 403-420.

Feldmann, J., 1937. Recherches sur la végétation marine de la Méditerranée. La Côte des Albères. Rev. Algol. 10, 1-339.

Hartog, C. DEN, 1957. Hydrocharitaceae. In: Flora Malesiana. Ed. by C. G. G. J. v. Steenis \& R. E. Holttum. Ser. 1. 5, 381-413.

- 1960. New sea-grasses from Pacific Central America. Pacif. Nat. 1, 15, 1-8.

- 1964a. An approach to the taxonomy of the sea-grass genus Halodule Endl. (Potamogetonaceae). Blumea 12, 289-312.

- 1964b. Typologie des Brackwassers. Helgoländer wiss. Meeresunters. 10, 377-390.

- \& SEGal, S., 1964. A new classification of the water-plant communities. Acta bot. neerl. 13, 367--393.

Humm, H. J., 1964. Epiphytes on the sea-grass Thalassia testudinum in Florida. Bull. mar. Sci. Gulf Caribb. 14, 306-341.

Kerneĩs, A., 1960. Contribution à l'étude faunistique et écologique des herbiers de Posidonies de la région de Banyuls. Vie Milieu 11, 145-187.

Lohmeier, W., c. s., 1962. Contribution à l'unification du système phytosociologique pour l'Europe moyenne et nord-occidentale. Melhoramento 15, 137-151.

MACNAE, W. \& KALK, M. (Eds), 1958. A natural history of Inhaca Island, Moçambique. Witwatersrand Univ. pr., Johannesburg, S. A., 163 pp.

- 1962. The flora and fauna of sand-flats at Inhaca Island, Moçambique. J. Anim. Ecol. 31, 93-128.

Mournier, R., 1960. Observations sur les phanérogames marines méditerranéennes. Rapp. P.-v. Réun. Commn. int. Explor. Mer Méditer. 15, 165-170.

- 1959-60. Etude des biocénoses marines du Cap Corse. Vegetatio 9, 121-192; 217-312.

- \& Picard, J., 1951. Biologie des herbiers de Zosteracées des côtes françaises de la Méditerranée. C. r. hebd. Séanc. Acad. Sci., Paris 233, 1212-1214.

Moore, D. R., 1963. Distribution of the sea-grass, Thalassia, in the United States. Bull. mar. Sci. Gulf Caribb. 13, 329-342.

Pham-Hoang Ho, 1961. Contribution à l'étude du peuplement du littoral rocheux du SudVietnam. Paris, Thèse, 198 pp.

Phillips, R. C., 1960. Observations on the ecology and distribution of the Florida sea-grasses. Prof. Pap. Ser. mar. Lab. Fla 2, 1-72.

STRAWN, K., 1961. Factors influencing the zonation of submerged monocoryledons at Cedar Key, Florida. J. Wildl. Mgmt. 25, 178-189.

Svedelius, N., 1904. On the life-history of Enalus acoroides. Ann. R. bot. Gdns Peradeniya 2, 267-297, Pl. 24 A-B.

Tanaka, T., Nozawa, K. \& Nozawa, Y., 1962. The distribution of sea-grasses in Japan. Acta phytotax. geobot., Kyoto 20, 180-183.

Thomas, L. P., Moore, D. R. \& Work, R. C., 1961. Effects of hurricane Donna on the turtle grass beds of Biscayne Bay, Florida. Bull. mar. Sci. Gulf Caribb. 11, 191-197.

Troul, W., 1931. Botanische Mitteilungen aus den Tropen. 2. Zur Morphologie und Biologie von Enbalus acoroides (LinN. f.) RICH. Flora 125, 427-456. 


\section{Discussion following the paper by DeN HARTOG}

Kesseler: Sie erwähnen, daß Seegrasarten nur wenig von Tierfraß befallen werden. Haben Sie eine Vorstellung, weshalb die Pflanzen als Futter gemieden werden? Enthalten die Zellen Substanzen, welche die Tiere veranlassen, sie zu verschmähen? Gibt es Literatur zu diesem Thema?

DEN HARTOG: I really do not know, why the sea-grasses are not popular as food for seaanimals. The dugong and the manetee seem to prefer them as food, but almost all other species seem to prey on the associated organisms.

REMMERT: Großpflanzen werden unter Wasser sehr häufig nicht von Tieren angegriffen - das gilt im Süßwasser für Potamogetonaceen, im Meer für Tange und Zostera. Sowie sie frisch angespült am Lande liegen, werden sie von vielen Tieren gefressen (Orchestia, Milben, Käfer, Fliegen): ich glaube daher nicht, daß chemische (toxische?) Stoffe eine Rolle spielen. Warum Großpflanzen im Wasser weniger als am Lande gefressen werden, kann ich mir auch nicht erklären.

Graccone: Est-ce que vous avez étudié le développement et la diffusion des phanerogames marines par rapport au procès de humification qui se realize dans le substrat où elles vivent?

Den Hartog: Sea-grasses establish themselves only on bottoms which already contain some organic matter. Due to accumulation of their debris and of the remains of their epiphytic flora and fauna they cause considerable changes in the composition of the upper layer of the bottom in the course of time. Further, the current velocity is slackened by their dense growth; this causes sedimentation of suspended material. This process of bottom-enrichment may be linked to some extent with the succession of sea-grass communities. There is no evidence, however, that the local distribution of the sea-grass communities is determined by this process.

Gessner: Posidonia oceanica hat im Mittelmeer eine Tiefengrenze bei etwa $45 \mathrm{~m}$. Wenn wir bedenken, daß Süßwasserphanerogamen nicht tiefer als $10 \mathrm{~m}$ vorkommen, stellt Posidonia einen Ausnahmefall dar. Er könnte dadurch bedingt sein, daß die Blätter mit zunehmender Tiefe die Gasräume reduzieren und dadurch unempfindlich gegen den hydrostatischen Druck werden.

Den Hartog: Posidonia oceanica aus seichtem Wasser hat große Luftkanäle und viele Interzellularen. Halopbila hat keine Luftkanäle und ist in dieser Hinsicht mehr mit zarten Algen $\mathrm{zu}$ vergleichen. Halopbila engelmanni wird noch autochthon angetroffen in einer Tiefe von $91 \mathrm{~m}$. Andere Angaben über Funde in großen Tiefen (Thalassia aus $80 \mathrm{~m}$ ) beziehen sich meines Erachtens auf verdriftetes Material. 